\title{
CURRENT DEVELOPMENTS IN OIL AND GAS INCOME TAXATION
}

\author{
JOHN G. McDONALD*
}

\begin{abstract}
Federal income taxation is an area of increasing concern to the resource industries. The author deals with current developments in the taxation field as they affect the oil and gas industry. The paper gives a general over-view of case law and statutes. The applicable budgets, both Federal and Provincial, are also discussed.
\end{abstract}

This paper, which is technical in nature, was prepared prior to the Alberta Budget of June 25, 1975 and the Federal Budget of June 23, 1975. Subsequent events are dealt with in footnotes (as of January 31, 1976).

$$
\text { PART 1-S.C. } 1974-75, \text { c. } 26
$$

\section{A. Royalty Addback and Phantom Income}

Since the Budget of May 6,1974, which was ably summarized at our last Conference, we have received the Budget of November 18, 1974 and Bill C-49 which, together with further amendments tabled in the House of Commons on February 10, 1975 has now been proclaimed in force as S.C. 1974-75 C. 26, which I shall call the "Amending Bill" for the purpose of this paper.

As many of you will have noted, the Amending Bill follows the drafting style of the so-called "new Act", and is therefore convoluted, turgid, loaded with "incorporation by reference" and therefore almost unintelligible.

Of even greater importance is the introduction by the Amending Bill of the first comprehensive tax on gross income, which is selectively applied to the oil and gas and mining industries for political purposes. In principle there is nothing to prevent the future application of this concept to the timber industry for the purpose of limiting Provincial revenues from that resource sector as well.

The principal sections of the amended Act are 12(1)(o), 18(1)(m), and 69(6)-(10). The first two of these measures have the combined effect of prohibiting the deduction of royalty and other "equivalent amounts" payable to the Provincial or the Federal Crown, and including such amounts in computing the income of oil and gas and mineral producers.

The amounts are defined as:

royalty or an equivalent amount, tax, rental, bonus, levy or otherwise or as an amount, however described, that may reasonably be regarded as being in lieu of a royalty or an equivalent amount, tax, rental, bonus, levy or other amount (whether such royalty or equivalent amount, tax, rental, bonus, levy or other amount is paid or payable pursuant to any other Act or a contract) that may reasonably be regarded as being in relation to:

(1) the acquisition development or ownership of a Canadian resource property, or a property that would have been a Canadian resource property if it had been acquired after 1971 , or

(2) the production in Canada of

(a) petroleum, natural gas or related hydrocarbons, or

(b) metal or industrial minerals to any stage that is not beyond the prime metal stage or its equivalent

from an oil or gas well or mineral resource situated on property in Canada from which the

- Barrister and Solicitor, McDonald and Hayden, Calgary, Alberta. 
taxpayer had, at the time of such production, a right to take or remove petroleum, natural gas or related hydrocarbons or a right to take or remove metal or industrial minerals.

The foregoing extract is taken from section $18(1)(\mathrm{m})$, and does not include the words "by a taxpayer" following the term "Canadian resource property", although the words "by a taxpayer" were added to section $12(1)(0)$ by the amendments tabled in the House of Commons on February 10, 1975.1 The reference to property that would have been a Canadian resource property if it had been acquired after 1971 is intended to include the oil sands, which are included in the definitions of "minerals" and "mineral resource" in section 248 of the Act. This change corrects an error in Bill C-49.

The royalties or equivalent amounts, etc., covered by sections $12(1)(0)$ and $18(1)(\mathrm{m})$ are amounts paid or payable to Canada or a Province, to an agent of Canada or a Province, to "a corporation, commission or association that is controlled, directly or indirectly in any manner whatsoever by Canada or a Province or by an agent of Canada or a Province." This last reference must certainly include corporations such as the Canada Development Corporation, PetroCanada, PanArctic Oils Limited, Polysar and other entities. In view of the fact that the prohibition of deduction and the inclusion in income applies to amounts that may reasonably be regarded as being in relation to the production in Canada of oil or gas from a well from which the taxpayer had, at the time of such production, a right to take or remove oil or gas, it seems to be clear that payments made by any working interest owner-and perhaps even by a corporation holding a gas delivery contract-that are made to any Crown corporation by way of over-riding royalty (or equivalent amount) will be non-deductible and will be includible in the income of the producer.

A special provision is made by sections 4(5) and 7(5) of the Amending Bill to exclude Crown lease bonuses from "royalty or an equivalent amount" where such bonuses were paid during the period May 7-November 18, 1974, and there is a general exception in the applicable sections of the Act of amounts paid to the Federal Crown in respect of leases of Indian land issued for the benefit of an Indian band.2

Although the foregoing provisions have effectively impaired the jurisdiction of Alberta and Saskatchewan to impose royalties on oil and gas production from Crown land in excess of a level acceptable to the Federal Government, they would, standing alone, have no impact on British Columbia, which has chosen to adopt a different system of disguised expropriation of hydrocarbon resources under Crown lease to producers.

In British Columbia, a Provincial Crown Corporation is used to purchase natural gas in the field at artificially low prices, and sell the gas produced in the British Columbia and United States markets at the substantially higher fair market value. The Amending Bill therefore introduced subsections (6) and (7) of section 69 of the Act to impose an equivalent gross income tax on producers in British Columbia. Section 69(6) provides that "where a taxpayer who operates an oil or gas well in Canadja disposes of any petroleum, natural gas or related hydrocarbons" to the Federal or the Provincial Crown, or to any Government controlled corporation, commission or association, "for no proceeds of disposition or for proceeds of

1 The words "by a taxpayer" may have been added to require the inclusion in a taxpayer's income only that portion of the Crown royalty that his interest is of the aggregate of all interests in a well.

2 Although a Crown lease bonus paid after November 18, 1974, is included in the non-deductible total of royalty or equivalent amounts under section $18(1)(\mathrm{m})$, the "first" bonus paid for a Crown lease remains deductible as a Canadian development expense under section 66.2(5)(a)(iv). 
disposition less than the fair market value thereof at the time he so disposes of it, he shall be deemed to have received proceeds of disposition therefor equal to that fair market value determined, in circumstances where he is required by a law or contract to so dispose thereof, without regard to that law or contract". It follows from this, for example, that if the British Columbia Crown Corporation fixes the well head price of gas produced by a particular producer at, say, 30 cents per mcf, and the fair market value of the gas produced is determined to be $\$ 1.00$ per mcf, the producer is deemed to have sold its production at $\$ 1.00$ per mcf, although he only receives 30 cents per mcf. The reference in the section to "no proceeds of disposition" is apparently designed to cover, in advance, the possibility of total expropriation of the industry by a particular Province, or to deal with the introduction of a joint venture system between a Provincial Government and industry in substitution for a royalty system. Section $69(7)$ also deals with this possibility by limiting the cost to a taxpayer of oil or gas production acquired from a Government or government agency to the fair market value of such production.

In the absence of any test of "fair market value" in Bill C-49, the Amending Bill was itself amended on February 10, 1975 by the addition of subsections (8)-(10) of section 69. Subsection (8) provides that for the purposes of subsection (6), the fair market value of production sold to the Crown or a Crown corporation or agency shall be deemed to be the amount by which the average proceeds of disposition that became receivable in a particular month by the Crown or a Crown agency for the disposition of similar production sold in the market exceeds the average aggregate of all expenses incurred by the Crown or Crown agency in that month for each sale of production that may reasonably be attributed to "transmitting, transporting, marketing or processing" the production to the extent that such expenses are reasonable and necessary, but not including any cost of acquisition.

The impact of the "royalty addback" and "phantom income" sections of the Income Tax Act are ameliorated by the so-called "tax abatement" of section $124(2.1)^{3}$ which provides that there may be deducted from tax otherwise payable (under Part 1 of the Act) by a corporation of an amount equal to, in 1975, 12\% and in 1976 and subsequent taxation years, 15\% of taxable production profits from oil and gas wells in Canada. Taxable production profits are defined by section $124.2(1)(b)$ as including the aggregate of the taxpayer's incomes for the year from the production of petroleum, natural gas or related hydrocarbons from oil or gas wells in Canada operated by him, and rentals or royalties, the amount of which are computed by reference to the amount or value of production from oil or gas wells in Canada. In view of the statutory language it would appear that royalty addback deemed income under section $12(1)(0)$ and phantom income under section 69(6) are includible in computing taxable production profits.

The effect of the abatement or tax credit under section $124(2.1)$ is a net corporate Federal tax rate of approximately $25 \%$ on taxable production profits, and this adjustment amounts to, in economic terms, the equivalent

\footnotetext{
Repealed by S.C. $1974-75$, c. 71 . Applies only to the 1974 and 1975 taxation years. For the 1976 and subsequent taxation years, replaced by section $20(1)(v .1),(15)$ which, subject to regulations not yet published, will allow as a "resource allowance", a deduction in computing income equal to $25 \%$ of resource production income calculated after operating expenses and capital cost allowances but before deduction of interest expense, exploration and development expenses and eamed depletion. The basic corporate tax rate is $46 \%$ effective January 1, 1976. The resource allowance, when prescribed, may not be granted to non-corporate taxpayers.
} 
of allowance as a deduction in computing income of provincial royalty rates of approximately $30 \%$. The tax abatement on taxable production profits is not granted to non-corporate producers. The practical effect of this clearly unfair discrimination is that, subject to the final form of the Alberta Petroleum Exploration Plan, incorporation of individually-owned production is mandatory by way of rollover under section 85(1) of the Act. ${ }^{4}$

\section{B. Resource Property Disposition}

Prior to the Amending Bill the provisions dealing with the tax treatment of proceeds of disposition of resource properties were relatively simple. Our federal draftsman had not yet gotten around to "reforming" section 83A of the former Act. The basic rule was that the proceeds of disposition of a resource property was includible in computing income, and a reserve was allowed for deferred proceeds of disposition, and there the matter ended with sections 59 and 64 . Today, with reference to most dispositions of resource properties after May 6, 1974, the statute requires close integration of the tax treatment of proceeds of disposition and deferred "revenue reserves" with new sections 66.1 and 66.2. Reference must also be made to a number of new subsections of section 66, and in this area, the drafting technique of incorporation by reference and double and triple cross reference now conforms to the computerized jungle style of the rest of the statute.

The simplest case, subject to section 66(12.4) (which is discussed in section (D) of this Part) is that where a taxpayer has disposed of a foreign resource property, the taxpayer's proceeds of disposition therefrom shall be included in computing his income for a taxation year to the extent that the proceeds become receivable in that year (section 59(1)).

The balance of former section 59(1) now appears in new section 59(1.1), which prescribes that the proceeds of disposition of a Canadian resource property "receivable" shall be included in the amount referred to in section $66.2(5)(\mathrm{b})(\mathrm{v})$. The amount referred to in that provision is "any amount that became receivable by the taxpayer after May 6, 1974 and before that time that is required to be included in the amount determined under this subparagraph by virtue of subsection 59(1.1)." After plowing through about forty similar cross references, one comes to the conclusion that the proceeds of disposition of a Canadian resource property is, in effect, deducted from the unapplied balance of a taxpayer's cumulative Canadian development expense, as defined by section 66.2(5)(b), in arriving at the amount, if any, which a taxpayer is entitled to deduct at the rate of $30 \%$, on a declining balance basis, under section 66.2(2). In other words, if a taxpayer's cumulative Canadian development expense is nil or negative, all or a portion of the proceeds of disposition of a Canadian resource property is brought into income subject to tax. Cumulative Canadian development expense, and cumulative Canadian exploration expense (section 66.1), are discussed in section $\mathrm{C}$ of this Part. The point now being made is that the tax treatment of proceeds of disposition must be integrated with what has come to be referred to as the "pool" system of accounting for Canadian development expenses, the deduction of which is treated very much like capital cost allowances in respect of depreciable property under section 20(1)(a) and Part XI of the Income Tax regulations.

Section 59(2) provides that, in a particular taxation year, any amount deducted as a reserve under section 64(1) of the Act for the immediately

- See footnote update in Part II, infra. Individuals now qualify for royalty tax credits and rebates in Alberta. 
preceding taxation year shall be included in computing the taxpayer's income. A similar inclusion is provided by section 59(2.1) in respect of any amount deducted as a reserve under section 64(1.1). Section 64(1), as before, provides for the deduction of a reserve of that part of the proceeds of disposition of any property that is not "due" (the word formally was "receivable") until a subsequent year. The concept of section 64(1) was similar to that of section 85B of the former Act with deferred revenue reserves. New section 64(1.1) then refers to amounts includible in income under new section 59(3.2)(c).

Turning back to that provision we find that it requires the inclusion in income of "any amount referred to in subsection 66.2(1)". Turning to section 66.2(1), we find that a taxpayer is required to include:

in computing the amount referred to in section $59(3.2)(\mathrm{c})$, the amount if any by which

(a) the aggregate of all amounts referred to in subparagraphs (5)(b)(iv) to (ix) that would be taken into account in computing his cumulative Canadian development expenses at the end of the year

exceeds

(b) the aggregate of all amounts referred to in subparagraphs (5)(b)(i) to (iii) that would be taken into account in computing his cumulative Canadian development expense at the end of the year.

After reduction of the cumulative Canadian devalopment expense of the taxpayer under section 66.2, any balance of a deferred receivable upon the disposition of a Canadian resource property, that is not due until after the end of the taxation year in which the calculations are made, may be deducted as a reserve under section 64(1.1).

A clue to the intention of Parliament, if one may presume to use that expression, appears in the marginal notes to section 59(3.1) and 66(12.4). The first of these is "Kecovery of exploration and development expenses". Section 59(3.2) provides that there shall be included in computing a taxpayer's income for a taxation year any amount referred to in any of sections $66(12.4)(b), 66.1(1)$, or $66.2(1)$. Section $66(12.4)$ is then marginally noted as "Limitation of foreign exploration and development expenses". This might lead one to believe that the draftsman intended to "recover" and "limit" exploration and development expenses, and sure enough, in section 66(12.4) we find an inclusion "in the amount referred to in Paragraph 59(3.2)(a)" of the excess of an amount receivable by the taxpayer over his undeducted foreign exploration and development expenses. This leads one to the conclusion that the other amounts includible in computing income under section 59(3.2) are, in fact, the balance of reserves otherwise deductible under section 64(1) and 64(1.1) and the income inclusion takes the form of a reduction of the taxpayer's cumulative Canadian development expense, producing positive income subject to tax when the CCDE account reaches zero. In other words, the proceeds of dispostion of resource properties in excess of the balance of a taxpayer's CCDE is brought into income subject to tax. It would appear that this provision is retroactive to May 6, 1974.

C. $E \& D, C E E, C D E, C C E E, C C D E$, etc.

Canadian exploration and development expenses (E \& D) as previously defined by section 66(15)(b), are limited to such expenses incurred before May 7,1974 . E \& D continues to be deductible under the former rules prescribed by subsections (1)-(3) of section 66. Principal business corporations must deduct the unapplied balance of $E \& D$ to the extent of income 
in a particular taxation year, and individuals or corporations other than principal business corporations may continue to deduct unapplied E \& D in an amount equal to the greater of $20 \%$ of the unapplied balance of $E \& D$ and the amount of income from the production of oil or gas wells in Canada.

Foreign E \& D incurred both before and after May 6, 1974 continues to be deductible under section 66(4) in an amount equal to the greater of $10 \%$ of the unapplied balance of foreign $\mathrm{E} \& \mathrm{D}$ and the taxpayer's aggregate production from foreign sources. For both domestic and foreign purposes, income includes royalties and the proceeds of disposition of resource properties.

The Amending Bill then takes over with the new concepts of Canadian exploration expense (CEE) and Canadian development expense (CDE) which replace Canadian E \& D after May 6, 1974.

CDE is substantially the same type of expense as that formerly described as $\mathrm{E} \& \mathrm{D}$. The definition is found in section $66.2(5)(\mathrm{a})$. The rate of deduction of CDE in a taxation year is any amount up to $30 \%$ of the unapplied balance of the taxpayer's cumulative Canadian development expense (CCDE), which is defined in section $66.2(5)(\mathrm{b})$. The rate of deduction of $30 \%$ applies to all taxpayers, corporate or non-corporate.

Canadian exploration expense (CEE) is deductible only by principal business corporations, and the effective rate of deduction is $100 \%$.PBC's must deduct $100 \%$ of their CEE to the extent of their incomes for the year under section 66.1(2). Individuals or corporations other than PBC's may deduct up to $30 \%$ of their CCEE at the end of each taxation year, under section $66.1(3)$.

The order of deduction of the various categories of exploration and development expenses is as follows:

1. Foreign D \& E,

2. CDE,

3. Old Canadian E \& D,

4. CEE.

The order of deduction is favourable to taxpayers with unapplied balances of old E \& D, which may be used in priority to CDE deductions which are "saved" for deduction in later years. Note the words "as he may claim" in section $66.2(2)$.

New successor-predecessor rules for the inheritance of Canadian E \& D are now collected in subsections (6) and (7) of section 66 . With reference to any transaction after 1971 predecessors and successor corporations need not be principal business corporations. The method of acquisition of all or substantially all of the property of a predecessor corporation includes an acquisition as a result of an amalgamation described in section $87(1)$. We comment further on this point in Part 3 of this paper in the context of the Gustauson case.

\section{Special Cases, Traps and Pitfalls \\ (1) depletion allowances}

The Minister of Finance announced, on November 18, 1974, that PartXII of the Income Tax Regulations will be amended to eliminate percentage depletion effective May 6, 1974. From and after May 7, 1974, depletion deductions will be based upon $\$ 1.00$ depletion for every $\$ 3.00$ of $E \& D, C D E$, and CEE incurred since introduction of the "new Act". Deductible depletion allowances on the $\$ 1.00$ for $\$ 3.00$ basis will be limited to $25 \%$ of annual production profits as a deduction from taxable income. At the date of 
writing, Part XII of the Regulations has not been amended to implement this change.

Part XII of the Income Tax Regulations will also be amended to accommodate the statutory amendments we are discussing. For example, reference to principal business corporations will be deleted in regulation 1204(4)(5) and regulation 1204(1) to make it clear that phantom income will be treated as taxable production profits for the purpose of depletion deductions. ${ }^{5}$ Regulation 1205 is expected to make it clear that the full cost of CEE and CDE (not including property costs) will be included in the earned depletion base. ${ }^{6}$

(2) conversion of interest on money borrowed for exploration

and development expenses into $C D E$

Section 21(2) of the Income Tax Act permits the elective treatment of interest on money borrowed for drilling and exploration work after May 6, 1974 as CEE or CDE. This subsection effectively permits taxpayers to transfer interest costs into the unlimited carryover position of exploration and development costs, and out of the business loss carryover provisions of the Act.

\section{(3) computation of adjusted cost base of partnership}

interests and corporate shares

In computing the adjusted cost base of an interest in a partnership (such as drilling fund) foreign exploration and development expenses, Canadian exploration and development expenses, CEE and CDE incurred by the partnership in its fiscal period are deductible. (Section $53(2)(\mathrm{c})(\mathrm{ii})(\mathrm{C})(\mathrm{d})$ ). Shares received in consideration for the funding of Canadian $E$ \& D, CEE and CDE are dealt with by section $53(2)(e)(f)(f .1)$. The adjusted cost base of such shares is reduced by the amount of expenses incurred by the corporation. These adjustment provisions are cross referenced to sections $66(15)(\mathrm{b})(\mathrm{v}), 66.1(6)(\mathrm{a})(\mathrm{v}), 66.2(5)(\mathrm{a})(\mathrm{vi})$ and $66(15)$ (drilling expense shares, shareholder corporations and joint exploration corporations).

\section{(4) salt and potash}

Under section 66(2), a corporation whose principal business is production or marketing of sodium chloride or potash or whose business includes manufacturing products the manufacturing of which involves processing sodium chloride or potash, may deduct, in computing its income for a taxation year, the drilling and exploration expenses incurred by it prior to May 7, 1974 on or in respect of exploring or drilling for halite or sylvite. Because halite and sylvite are included in the definition of "mineral resource" in section 248, all taxpayers are entitled to deduct CDE incurred for the purpose of bringing a salt or potash property into production prior to the commencement of production from the resource in reasonable commercial quantities. The cost of shaft sinking is included in the definition (section 66.2(5)(a), 66.2(2)).

The definition of principal business corporation under section $66(15)(\mathrm{h})$ includes a corporation whose principal business is production or marketing of sodium chloride or potash, or whose business includes manufacturing products the manufacturing of which involves processing sodium chloride

$\therefore$ See Regulation 1204(b), P.C. 1975-1323.

- See Regulation 1205(a)(i)(ii)(iii), P.C. 1975-1323. 
or potash. Such corporations therefore qualify under section $66.1(2)$ for the right to deduct $\mathrm{CEE}$ at the $100 \%$ rate.

(5) joint exploration corporations

The renunciation of CEE and CDE by a joint exploration corporation is covered by section $66(10.1)(10.2)$.

(6) stop-loss provision

Section 66(11) has been amended to cut off the carry over of undeducted CEE and CDE where there is an acquisition of control of an inactive corporation.

(7) drilling or exploring "for an interest"-deductions disallowed

Section 66(12.1), with reference to transactions after May 6, 1974, provides that where an amount has become receivable in consideration for services the original cost of which to the taxpayer may reasonably be regarded as having been primarily Canadian $\mathrm{E} \& \mathrm{D}, \mathrm{CEE}$, or CDE, the amount that became receivable must be deducted from the taxpayer's CCEE or CCDE account, as the case may be. The effect of this provision is that where a drilling contractor or geophysical company drills or explores for an interest in the property of a third party, the drilling and exploration expenses, in effect, incurred by the contractor are not deductible. A similar limitation is placed upon foreign $\mathrm{E} \& \mathrm{D}$ by section 66(12.4). Both subsections (12.1) and (12.4) have the effect of adding back "the amount that became receivable" by the taxpayer, and where such amount receivable (which may exceed the cost of drilling) exceeds the balance of the taxpayer's CCEE, CCDE or foreign E \& D account, it would appear that the excess is brought into income subject to tax. In view of the definition of "amount" in section 248 , this inclusion could be quite substantial in the case of a discovery well.

The subsections also apply to inter-company sales of seismic and geophysical data.

(8) unit $E \& D$ contributions

Subsections (12.2) and (12.3) of section 66 provide that where one member of an oil or gas unit contributes to the Canadian E \& D, CEE or CDE of another member of the unit, the contribution is deductible from the C \& $D$, CCEE or CCDE of the payee, and included in the corresponding account of the payor.

\section{(9) delay rentals}

The definition of pre-May 7, 1974 Canadian E \& D (section 66(15)(b)) has been amended to include "any annual payment made by the taxpayer for the preservation of a Canadian resource property or property that would have been a Canadian resource property if it had been acquired by the taxpayer after 1971". Foreign exploration and development expenses, as defined by section 66(15)(e), includes delay rentals. Canadian delay rentals incurred after May 6, 1974, however, are not included in the definition of CDE (section $66.2(5)(a)$ ), although Departmental officials have said that they understand that such rentals will be deductible under the general law. The more widely held opinion on this point is that if the matter were put to a test, delay rentals would probably be held to be non-deductible capital expenditures for the preservation of property.

(10) the Iron Bay Trust amendment

Section 66(15)(c)(vi) includes within the definition of "Canadian 
Resource Property" any right to or interest in any property described in subparagraphs (i)-(v). This inclusion was amended to exclude "property of a trust" and to include "a right to receive proceeds of disposition in respect of a disposition" of a Canadian resource property.

The exclusion of property of a trust was intended to overrule, for the 1974 and subsequent taxation years, an advance tax ruling under which units of the Iron Bay Trust, which are listed on the Toronto Stock Exchange, were held to be Canadian resource property.

\section{(11) disposition of Canadian resource property by non-resident persons}

Subparagraph (iii.1) of section $115(1)$ (a) has been amended, applicable to transactions after May 6, 1974, to include in the income of a non-resident person from the disposition of taxable Canadian property, proceeds of disposition of resource properties "receivable" in the year. Section 126(2.2) has been added to the Act applicable to the 1974 and subsequent taxation years, to allow a foreign tax credit in respect of foreign capital gain taxes payable in respect of a disposition of a Canadian resource property by a former Canadian resident after he ceased to be resident in Canada.

\section{(12) non-resident withholding tax on payments from \\ one non-resident to another}

Section 212(13.2) was added to the Act, applicable to amounts paid or credited after November 18,1974 . This new subsection provides that where a non-resident person who operates an oil or gas well in Canada, or extracts minerals from a mineral resource in Canada, pays or credits an amount to another non-resident person, "he shall be deemed in respect of the portion of that amount that was deductible in computing his taxable income earned in Canada for any taxation year, to be a person resident in Canada". This amendment appears to conflict with subsection (2) of Article XII of the Canada-U.S. Tax Convention, which provides, inter alia, that "interest paid by a corporation organized under the laws of the United States of America whose business is not managed or controlled in Canada to a recipient, other than a resident in Canada or a corporation whose business is managed and controlled in Canada, shall be exempt from all taxes imposed by Canada".

\section{(13) computation of post-1971 undistributed surplus}

Tax is imposed at the rate of $25 \%$ on dividends paid out of designated surplus of a corporation, and "post-1971 undistributed surplus" is an ingredient in such designated surplus. Such post-1971 surplus is defined by section 192(15) as "the aggregate of [the corporation's] incomes for taxation years beginning with the 1972 taxation year and ending with the particular year, minus the aggregate of . . . each expense incurred or disbursement made by the corporation during such year that was not allowed as a deduction in computing income for any of those years under Part I . . .". The question now arises whether a royalty or an equivalent amount, etc., as described by section $18(1)(\mathrm{m})$, qualifies as an expense that was not allowed as a deduction in computing income, for the purpose of determining the designated surplus of a corporation. It would appear that Federal officials intend to ignore Provincial law, and treat such amounts as disallowed expenses for the purpose of Part VII and VIII of the Act. However, because royalties constitute the share of production belonging to the Provincial Crown, it will be a bold tax advisor indeed who proceeds with any transaction involving a calculation of designated surplus without obtaining an advance tax ruling on this point. 


\section{PART II-ALBERTA PETROLEUM EXPLORATION PLAN (APEP)}

Alberta's response to the Federal Budget of November 18, 1974 was APEP, announced on December 12, and revised on January 22, 1975. The two basic measures of APEP are a rebate of Alberta corporate income tax on royalty, and a royalty tax credit.?

The corporate income tax refund is a refund of corporate income taxes payable to Alberta as a result of the non-deductibility, under section $18(1)(\mathrm{m})$ of the Federal Income Tax Act, of royalties and equivalent amounts on oil, natural gas and natural gas products, payable to all governments, in computing taxable income. The refund applies to Alberta tax on income allocated to Alberta under Part XXVI and IV of the Federal Income Tax Regulations. At the current corporate tax rate, the Provincial refund is equivalent to $11 \%$ of non-deductible payments to governments in Canada allocated to permanent establishments in Alberta. The amount of the refund cannot exceed Alberta corporate income tax payable in a particular taxation year, but any excess refund may be carried forward and applied against future taxes payable. Alberta anticipates that the refund program will be administered by the Department of National Revenue.

Under the second half of the program, the tax credit for small explorers calls for the allowance of credits against Alberta corporate tax payable (net of the refund of corporate tax on royalties) of $30 \%^{8}$ of royalties disallowed under section 18(1)(m) of the Federal Income Tax Act, up to $\$ 1$ million for each full taxation year. Where the small explorer's credit exceeds Alberta corporate tax payable, the excess will be paid as a cash refund.

The aggregate annual tax credit and/or cash refund is expected to be equal to the lesser of:

(a) $30 \%$ of the conventional crude oil, natural gas, and natural gas products royalties payable to Alberta in the taxation year that were not allowed as a deduction in computing taxable income, and

(b) \$1 million to corporations or groups of associated corporations paying royalties to Alberta on oil and gas well production in Alberta.

The question has been raised whether the corporate income tax refunds and cash refunds under APEP might themselves be assessed as business income by the Department of National Revenue. I think that this is unlikely in view of the December 1974 statement of the Federal Minister of Finance welcoming the APEP announcement as an acceptable drawback by the Province in the tax-royalty conflict. Indeed, as the Income Tax Act now stands, there is a precedent against any such assessment in the case $K . I$. German, 59 DTC 420. The German case involved payments of $\$ 20.00$ to every resident of Alberta out of the "Citizens Dividend Fund" established in 1957 under a statute captioned "an Act to enable citizens of Alberta to participate directly in the benefits accruing in the development of the oil and gas resources of the Province". The Tax Appeal Board held, of course, that the so-called dividends were not dividends, but gifts from the Alberta Government, and therefore not taxable as income.

However, the case of GTE Sylvania Canada Ltd. v. The Queen, 74 DTC 6673 indicates the length to which the Federal Department of National Revenue will go to interfere with Provincial Tax concessions. Under former section $17(7)(e)$ the capital cost of depreciable property was required to be

\footnotetext{
; Both corporate and individual producers now qualify. See sections 8.4 and 8.5, S.A. 1975, c. 22.

* $28 \%$ in 1975 and $25 \%$ in 1976 and subsequent years. The royalty tax credit for individuals is $25 \% \%$, not to exceed \$1 Million a year.
} 
reduced, for federal tax purposes, by the amount of any government "grant, subsidy or other assistance". In the Sylvania case, the Federal Court of Appeal has affirmed the Trial Division decision that Quebec income tax reductions resulting from qualifying investments in plant and equipment in Quebec did not constitute a grant, subsidy or other assistance under former section 13(7)(e). The Federal Department has appealed that decision to the Supreme Court of Canada, and the Government has amended the Income Tax Act by the introduction of section 13(7.1), which provides that, with reference to all acquisitions of depreciable property after November 18, 1974, depreciable capital cost must be reduced by the amount of any govenmental assistance "whether as a grant, subsidy, forgiveable loan, deduction from tax, investment allowance or as any other form of assistance". It is clear that if this wording were used in a general provision designed to attack Provincial incentives to the oil and gas industry, it would catch the tax rebates and tax credits announced under APEP.

Of course, it is inconceivable that the Federal Government would agree to administer a Provincial plan such as APEP, while secretly planning its demolition through legislation similar to section 13(7.1). In view of what has occurred during the past year, such action would clearly precipitate a constitutional crisis of major proportions. ${ }^{9}$

Reference should also be made to a policy statement by the Provincial Treasurer on January 29,1975, and to the forthcoming Alberta Budget. Alberta proposes to use the corporate tax system to provide additional incentives to small business in the Province, and to stimulate the Provincial economy. APEP is only one of these programs.

\section{PART III-CASE LAW AND BULLETINS}

\section{A. Predecessor-Successor Corporations, section 66(6)(7)(8)(9)}

In the context of the case of Gustauson Drilling (1964) Ltd., 75 DTC 5451 the amendment of the predecessor-successor provisions of former section $83 \mathrm{~A}$ of the Income Tax Act will undoubtedly be affected by the ultimate decision of the Supreme Court. As noted in Part I of this paper a successor corporation may inherit the Canadian E \& D, CDE, and CEE of a predecessor corporation, and neither corporation is now required to be a principal business corporation. The amendments apply to taxation years ending after May 6,1974. The question now arises whether a double deduction of Canadian E \& D has been permitted. Under the prior law, a property transfer from PBC to a non-PBC in 1972 or 1973 , which was not a succession under section 66(6) of the Act in the year in which the transaction occurred, is now a qualified succession for the 1974 and subsequent taxation years because it is no longer necessary to be a PBC in order to inherit Canadian E \& D. We may therefore have one or more new cases in which a predecessor corporation competes with another corporation for the same Canadian E \& D, because the new provisions apply to any acquisition of property after 1971 , by purchase or otherwise including an amalgamation described in subsection 87(1). See also sections $66.1(4)(5), 66.2(3)(4)$.

\footnotetext{
9 See comment on the constitutional question: Rae, Current Developments in Oil and Gas Income Taxation, (1975) 13 Alberta Law Review 46 at 61, footnote 38. See also I.T. Bulletins 249, 250, 251, 152 dealing with Provincial Government assistance to industry. In particular see number 251 concerning Ontario's Mineral Exploration Assistance Program.
} 


\section{B. Seismic and Geophysical Data Costs-deductible as Ordinary Business Expenses}

The question raised at last year's Foundation Conference concerning so-called "sham transactions" and the proper tax treatment of ordinary income expenditures, ${ }^{10}$ appear to have been settled definitively by the judgment of the Federal Court (Trial Division) in the appeal of Sigma Explorations Ltd. v. The Queen, 75 DTC 5121. The Sigma case involved the deductibility of the cost of purchased seismic data and geophysical information in the form of digitized well logs. The main issue was the deductibility of $\$ 214,000.00$ paid to the Plaintiff's parent company for a call upon digitized well log information from a very substantial library of such data owned by Sigma's parent company. The Defendant argued that the transaction of purchase and sale was a "sham", alternatively that it unduly or artificially reduced the Plaintiff's income, and in the last alternative that it was a capital expenditure. The position taken by the Department of National Revenue was rejected on all counts.

Dealing with the "sham" argument, Collier J. referred to the judgment of Diplock L.J. in Snook v. London and West Riding Investments, Ltd.,"1 and concluded that "the transactions between the Plaintiff and its parent company, including the documents, were not intended .... to give to anyone the appearance of creating rights and obligations different from those the parties intended. "There was in this case no dissembling, masquerading, or lack of bona fide intention".

Dealing with former section 137(1) (now section 245(1)) of the Income Tax Act, the learned judge said that:

Parliament has not defined the meaning of the phrase "unduly or artificially reduce the income". The taxpayer, in carrying on of his business affairs, is left to speculate on the arcane intention of the legislator, and the perhaps unpredictable attitude or opinion of the Minister in each individual case. As I understand the process, initially the Minister reviews the evidence available to him, and then by assessment or reassessment indicates his opinion that the particular disbursement would, if allowed, unduly or artificially reduce income. If that legally-undebatable opinion were conclusive or over-riding, the Revenue Department could indirectly control the nature, purpose and amounts of a vast number of commercial expenditures. The test in deciding whether a deduction is prohibited by ss. 137(1) [ss. 245(1)] must, as I see it, be an objective one .... in the final analysis the overall finding of undueness or artificially (or not) is a value judgment based on all the facts and factors. Undoubtedly, many expenditures arithmetically reduce a taxpayer's income ... If, however, the expenditure is a reasonable one for legitimate income-earning and business purposes, and not in its true light a vehicle primarily to minimize tax, then no matter how drastically income may be diminished, I do not think the transaction can, or ought to be, at the same time characterized as an unreasonable reduction of income, or unreal or un-natural reduction.

The learned judge then adopted the words of Noel A.C.J. in Jones Tobacco Sales: ${ }^{2}$ "one might consider the practical and commercial aspects of the transaction in question, and not merely the legal aspects."

So endeth the battle that was joined in M.N.R. v. Cameron. ${ }^{13}$

11 See references to M.N.R. v. Clifford Clark, 74 D.T.C. 6242, also, Chibougamau Lumber Ltd. [1973] CTC 2174 in Rae, Current Developments in Oil and Gas Income Taxation, (1975) 13 Alberta Law Review 46 at 56-58.

" [1967] 1 All E.R. 518 at $528^{4}$. . . for acts or documents to be a sham' with whatever legal consequences follow from this, all the parties thereto must have a common intention that the acts or documents are not to create the legal rights and obligations which they give the appearance of creating."

12 [1973) F.C. 825 at 834.

:" [1972] C.T.C. 380. 
C. Surface Rentals and Farming Operations-

I.T. Bulletin 200

I.T. 200, dated February 24, 1975 summarizes the rules for assessing purposes governing the tax treatment to the freehold owner of payments made for surface rights of entry. Because the text of the Bulletin is widely reported, I will not summarize it here. 